\title{
Dietary calcium concentration and cereals differentially affect mineral balance and tight junction proteins expression in jejunum of weaned pigs
}

\author{
Barbara U. Metzler-Zebeli ${ }^{1,2 *}$, Evelyne Mann ${ }^{2,3}$, Reinhard Ertl ${ }^{4}$, Stephan Schmitz-Esser ${ }^{2,3}$, \\ Martin Wagner ${ }^{2,3}$, Dieter Klein ${ }^{4}$, Mathias Ritzmann ${ }^{5}$ and Qendrim Zebeli ${ }^{2,6}$ \\ ${ }^{1}$ University Clinic for Swine, Department for Farm Animals and Veterinary Public Health, \\ University of Veterinary Medicine Vienna, Veterinärplatz 1, 1210 Vienna, Austria \\ ${ }^{2}$ Research Cluster 'Animal Gut Health', Department for Farm Animals and Veterinary Public Health, \\ University of Veterinary Medicine Vienna, Vienna, Austria \\ ${ }^{3}$ Institute of Milk Hygiene, Department for Farm Animals and Veterinary Public Health, \\ University of Veterinary Medicine Vienna, Vienna, Austria \\ ${ }^{4}$ VetCore Facility for Research, University of Veterinary Medicine Vienna, Vienna, Austria \\ ${ }^{5}$ Clinic for Swine, Ludwig-Maximilians-Universität München, Oberschleißheim, Munich, Germany \\ ${ }^{6}$ Institute of Animal Nutrition and Functional Plant Compounds, Department for Farm Animals and \\ Veterinary Public Health, University of Veterinary Medicine Vienna, Vienna, Austria
}

(Submitted 15 September 2014 - Final revision received 21 December 2014 - Accepted 16 January 2015 - First published online 12 March 2015)

\section{Abstract}

Ca plays an essential role in bone development; however, little is known about its effect on intestinal gene expression in juvenile animals. In the present study, thirty-two weaned pigs $(9.5$ (SEM $0 \cdot 11) \mathrm{kg}$ ) were assigned to four diets that differed in Ca concentration (adequate $v$. high) and cereal composition (wheat-barley $v$. maize) to assess the jejunal and colonic gene expression of nutrient transporters, tight junction proteins, cytokines and pathogen-associated molecular patterns, nutrient digestibility, Ca balance and serum acute-phase response. To estimate the impact of mucosal bacteria on colonic gene expression, Spearman's correlations between colonic gene expression and bacterial abundance were computed. Faecal $\mathrm{Ca}$ excretion indicated that more $\mathrm{Ca}$ was available along the intestinal tract of the pigs fed high Ca diets as compared to the pigs fed adequate Ca diets $(P<0.05)$. High Ca diets decreased jejunal zonula occludens 1 (ZO1) and occludin (OCLN) expression, up-regulated jejunal expression of toll-like receptor 2 (TLR2) and down-regulated colonic GLUT2 expression as compared to the adequate Ca diets $(P<0.05)$. Dietary cereal composition up-regulated jejunal TLR2 expression and interacted $(P=0.021)$ with dietary $\mathrm{Ca}$ on colonic IL1B expression; high Ca concentration up-regulated IL1B expression with wheat-barley diets and down-regulated it with maize diets. Spearman's correlations $(r>0.35 ; P<0.05)$ indicated an association between operational taxonomic units assigned to the phyla Bacteroidetes, Firmicutes and Proteobacteria and bacterial metabolites and mucosal gene expression in the colon. The present results indicate that high Ca diets have the potential to modify the jejunal and colonic mucosal gene expression response which, in turn, interacts with the composition of the basal diet and mucosa-associated bacteria in weaned pigs

\section{Key words: Calcium: Intestinal mucosa: Gene expression: Dietary cereal: Juvenile pigs}

In addition to the well-established critical role that sufficient $\mathrm{Ca}$ intake plays in skeletal development and health ${ }^{(1,2)}$, there has been growing evidence that dietary $\mathrm{Ca}$ has further benefits, commencing in the intestinal lumen, where Ca was shown to exert anti-inflammatory and cytoprotective effects when it was available at higher luminal concentrations ${ }^{(3-5)}$. These effects were linked to the high buffering property of
$\mathrm{Ca}$, which abrogated negative aspects of intense fermentation in the intestinal lumen on mucosal integrity in rodent models $^{(5)}$. Moreover, luminal $\mathrm{Ca}$ is essential for intestinal epithelial function, because it affects the composition of intestinal plasma membranes and para- and transcellular Ca transport either directly via the modulation of signalling pathways or indirectly via the modification of the vitamin $\mathrm{D}$ endocrine

Abbreviations: ATTD, apparent total tract digestibility; GLUT2, solute carrier family 2 (facilitated glucose transporter), member 2; INFG, interferon- $\gamma$; LPS, lipopolysaccharide; OCLN, occludin; OTU, operational taxonomic units; SGLT1, solute carrier family 5 (sodium/glucose cotransporter), member 1; $S M C T$, sodium-coupled monocarboxylate transporter; TGFB1, transforming growth factor- $\beta$ 1; TLR, toll-like receptor; ZO1, zonula occludens 1 . 
response ${ }^{(6,7)}$. In adult rodents, the colon was proposed as the main intestinal site of action for $\mathrm{Ca}^{(8)}$. In a recent study with weaned pigs, however, we found that the main responding intestinal site was the small intestine and not the colon ${ }^{(9)}$. Overall, Ca effects on the intestinal mucosa in the juvenile phase have not been explored in detail, and there is little information available about the potential effects of high $\mathrm{Ca}$ intake on the intestinal digestive, absorptive, immunal and barrier functions of young animals. Young mammals, like pigs, are very vulnerable to intestinal perturbations in the immediate phase after weaning because of the immaturity of their mucosal immunity, digestive capacity and microbiota $^{(10,11)}$, and they may benefit from the anti-inflammatory and cytoprotective effects of extra dietary $\mathrm{Ca}$. The composition of the dietary complex carbohydrate fractions may mitigate the effect of high dietary Ca supply either by stimulating intestinal $\mathrm{Ca}$ absorption or by complexing Ca intestinally ${ }^{(9)}$. Whole grains are typical sources of dietary fibre in human and animal diets; however, common dietary cereals, such as wheat, barley and maize, largely differ in their cellulose and hemicellulose fractions ${ }^{(12)}$. Therefore, potential $\mathrm{Ca}$ effects on intestinal mucosal functions should be investigated when considering differences between the complex carbohydrate fractions of the basal diet to account for the interaction between dietary $\mathrm{Ca}$ concentration and dietary cereals. Thus, we hypothesised that a dietary $\mathrm{Ca}$ intake that is much higher than the actual requirement may reduce intestinal pro-inflammatory cytokine expression and also up-regulate the expression of nutrient transporters and tight junction proteins in the small and large intestines of young pigs and that dietary cereal composition would interact with dietary $\mathrm{Ca}$ concentration in intestinal gene expression.

Aside from direct regulation ${ }^{(10,13)}$, dietary ingredients modulate the intestinal mucosal response by altering the intestinal microbiota and their metabolites which are generated during the fermentation of diet-derived substrates ${ }^{(14)}$. Consequently, dietary composition, including carbohydrate fractions and micronutrient concentrations, can be targeted to selectively stimulate bacteria with known health-promoting effects for the host ${ }^{(14-18)}$. Due to their ultimate proximity to the enterocytes, it is accepted that intestinal mucosa-associated microbiota have a significant impact on mucosal gene and protein expression $^{(14)}$. Considering these findings, we further hypothesised that the mucosal expression of genes would be connected to specific mucosa-associated bacteria and luminal microbial metabolites independently of the composition of the diet fed to the animals.

To test our hypotheses, the present study was designed to investigate the effect of dietary $\mathrm{Ca}$ concentration on the expression of candidate genes that target nutrient absorption, barrier function and mucosal inflammatory response in the jejunum and colon of male weaned pigs. In addition, indirect estimates of digestion and absorption, which were based on apparent total tract digestibility (ATTD) and the retention of nutrients, were applied to study the influence of $\mathrm{Ca}$ on intestinal nutrient uptake, and serum acute-phase proteins were determined as markers of systemic inflammation. To evaluate potential $\mathrm{Ca} \times$ dietary cereal interactions on intestinal mucosa and nutrient digestion, two basal diets with contrasting cereals (wheat-barley $v$. maize) were formulated. The relationship between mucosal gene expression and mucosa-associated bacteria and luminal microbial metabolites was assessed for the colon using recently published data ${ }^{(17,18)}$.

\section{Materials and methods}

The experimental design and methods have been described in detail recently ${ }^{(17-19)}$.

\section{Animals and experimental design}

All procedures involving animal handling and treatment were approved by the institutional ethics committee of the University of Veterinary Medicine Vienna and the national authority according to $\$ 8 f f$ of the Law for Animal Experiments, Tierversuchsgesetz - TVG (GZ 68.205/0222-II/3b/2011). In the present study, weaned barrows ( $n$ 32; (Landrace $\times$ Large White) $\times$ Piétrain; average body weight 9.5 (sEm 0.11$) \mathrm{kg}$; weaning age $28 \mathrm{~d}$ ) were randomly allocated to four diets ( $n$ 8/diet) comprising either wheat and barley or maize as cereals and containing either adequate or high concentrations of $\mathrm{Ca}$ (Table 1). The experiment consisted of nine blocks with eight pigs each, with two pigs per run being fed the same diet. In each run, pigs had ad libitum access to the experimental diets for $15 \mathrm{~d}$ from day 8 post-weaning (experimental day 1). We used castrated male pigs in order to be able to collect urine and faeces separately.

Diets met or exceeded the current nutrient requirements for pigs between 10 and $20 \mathrm{~kg}^{\text {(20) }}$ (Table 1) and were formulated to be isoenergetic and isonitrogenous. Because of the higher fat contencentration in maize, diets differed in their fat source and thus their fatty acid composition. Wheat-barley diets contained 3\% soya oil, whereas maize diets contained only $1.5 \%$ soya oil. Diets adequate in Ca were formulated to meet $100 \%$ of the pigs' $\mathrm{Ca}$ and $\mathrm{P}$ requirements, and high $\mathrm{Ca}$ diets were formulated to contain $\mathrm{Ca}$ and $\mathrm{P}$ at a concentration of $190 \%$ of the $\mathrm{Ca}$ and $\mathrm{P}$ requirement for $10-20 \mathrm{~kg}$ pigs ${ }^{(20)}$. The calculated $\mathrm{Ca}$ and $\mathrm{P}$ concentration of adequate $\mathrm{Ca}$ diets amounted to $8.0 \mathrm{~g} \mathrm{Ca}$ and $6.1 \mathrm{~g} \mathrm{P} / \mathrm{kg}$ diet (DM basis), whereas the calculated $\mathrm{Ca}$ and $\mathrm{P}$ concentration of high $\mathrm{Ca}$ diets were $15.1 \mathrm{~g} \mathrm{Ca}$ and $11.7 \mathrm{~g} \mathrm{P} / \mathrm{kg}$ diet (DM basis). Thus, the calculated $\mathrm{Ca}: \mathrm{P}$ ratio was $1 \cdot 3: 1$ for all diets so that any potential $\mathrm{Ca}$ effects on the intestinal mucosa would not be compromised by a diverging Ca:P ratio, as reported in rats ${ }^{(4)}$. Microbial phytase was added to the diets to compensate for the different intrinsic phytase activities in wheat, barley and maize ${ }^{(21)}$. Representative diet samples were taken in each experimental block. Feed leftovers (spillage and feed left in the trough) were collected each morning at 08.00 hours before fresh feed was provided. Animals had free access to demineralised water. Pigs were weighed at the commencement, on day 9 and day 15 (end) of the experiment. One pig that had been fed the wheat-barley diet high in $\mathrm{Ca}$ was removed from the experiment because it developed meningitis at the commencement of the experiment. 
Table 1. Ingredients (as-fed basis) and analysed chemical composition of the experimental diets ${ }^{(16-18)}$

\begin{tabular}{|c|c|c|c|c|}
\hline \multirow[b]{2}{*}{ Ingredient (g/kg) } & \multicolumn{2}{|c|}{ Wheat-barley diet } & \multicolumn{2}{|c|}{ Maize diet } \\
\hline & Adequate $\mathrm{Ca}$ & High Ca & Adequate $\mathrm{Ca}$ & High Ca \\
\hline Maize & - & - & $494 \cdot 0$ & 494.0 \\
\hline Wheat & 352.0 & 352.0 & - & - \\
\hline Soyabean meal & $280 \cdot 0$ & $280 \cdot 0$ & 335.0 & 335.0 \\
\hline Barley & $182 \cdot 0$ & $182 \cdot 0$ & - & - \\
\hline Dextrose & $50 \cdot 0$ & $50 \cdot 0$ & $50 \cdot 0$ & $50 \cdot 0$ \\
\hline Talkum & $33 \cdot 2$ & $2 \cdot 7$ & $34 \cdot 3$ & 4.0 \\
\hline Saccharose & $30 \cdot 0$ & $30 \cdot 0$ & 30.0 & 30.0 \\
\hline Soya oil & $30 \cdot 0$ & $30 \cdot 0$ & $15 \cdot 0$ & $15 \cdot 0$ \\
\hline Limestone & $13 \cdot 0$ & 19.5 & $12 \cdot 5$ & $19 \cdot 3$ \\
\hline Salt & $10 \cdot 0$ & $10 \cdot 0$ & $10 \cdot 0$ & $10 \cdot 0$ \\
\hline Monocalcium phosphate & 7.5 & 31.5 & 8.5 & $32 \cdot 0$ \\
\hline Vitamin-mineral premix ${ }^{*}$ & $6 \cdot 3$ & $6 \cdot 3$ & $6 \cdot 3$ & $6 \cdot 2$ \\
\hline Lys & 3.5 & 3.5 & $2 \cdot 4$ & 2.5 \\
\hline L-Thr & 1.5 & 1.5 & 1.0 & 1.0 \\
\hline DL-Met & 1.0 & 1.0 & 1.0 & 1.0 \\
\hline Phytase $(\mathrm{FTU} / \mathrm{kg}) \dagger$ & 500 & 500 & 500 & 500 \\
\hline \multicolumn{5}{|c|}{ Analysed chemical composition (DM basis, $\mathrm{g} / \mathrm{kg}$ ) } \\
\hline DM & 929 & 917 & 921 & 929 \\
\hline Crude protein & 222 & 223 & 222 & 218 \\
\hline Crude ash & 94 & 96 & 95 & 96 \\
\hline Crude fibre & 36 & 37 & 36 & 36 \\
\hline Xylose & 16 & 18 & 11 & 12 \\
\hline$\beta$-Glucan & 9 & 9 & 1 & 1 \\
\hline Neutral-detergent fibre & 117 & 122 & 112 & 104 \\
\hline Acid-detergent fibre & 85 & 79 & 83 & 68 \\
\hline Total starch & 302 & 310 & 299 & 301 \\
\hline $\mathrm{Ca}$ & $8 \cdot 2$ & $14 \cdot 8$ & 8.4 & $14 \cdot 1$ \\
\hline $\mathrm{P}$ & $6 \cdot 0$ & 11.9 & $6 \cdot 6$ & 11.7 \\
\hline Ca:P ratio & 1.37 & 1.24 & 1.27 & $1 \cdot 21$ \\
\hline Gross energy (Mcal/kg) & 4.00 & 4.01 & 4.05 & 3.99 \\
\hline \multicolumn{5}{|c|}{ Calculated chemical composition (DM basis, $\mathrm{g} / \mathrm{kg}$ )‡ } \\
\hline Metabolisable energy (MJ/kg) & $15 \cdot 11$ & $15 \cdot 15$ & $15 \cdot 22$ & $15 \cdot 27$ \\
\hline Metabolisable energy (Mcal/kg) & 3.61 & 3.63 & 3.63 & 3.65 \\
\hline
\end{tabular}

\section{Balance and digestibility study}

After $9 \mathrm{~d}$ of dietary treatment, pigs' faeces and urine were quantitatively collected from day 10 to day 14 for determination of nutrient digestibility and $\mathrm{N}, \mathrm{Ca}$ and $\mathrm{P}$ balances. The total amounts of faeces and urine produced were recorded during collection. Fresh faecal samples were collected several times daily and frozen at $-20^{\circ} \mathrm{C}$. Urine was collected in buckets containing $25 \mathrm{ml}$ of $18.75 \mathrm{M}^{-} \mathrm{H}_{2} \mathrm{SO}_{4}$ (VWR International) to minimise microbial fermentation for $24 \mathrm{~h}$, weighed and filtered. Representative subsamples $(250 \mathrm{ml})$ were pooled over the $4 \mathrm{~d}$ collection period, kept at $4^{\circ} \mathrm{C}$ during the collection days and stored at $-20^{\circ} \mathrm{C}$ until analysis.

\section{Sampling of blood and jejunal and colonic mucosa}

On day 15 of the experiment, $3-4 \mathrm{~h}$ after receiving fresh feed, animals were anaesthesised (Narketan, $10 \mathrm{ml} / \mathrm{kg}$ body weight; Ketamine $\mathrm{HCl}$; Vétoquinol $\mathrm{AG}$ and Stresnil, $3 \mathrm{ml} / \mathrm{kg}$ body weight; Azaperone; Biokema SA); blood was collected by cardiac puncture into serum collection tubes (Primavette; KABE Labortechnik) and placed on ice until further processing.
Blood samples were centrifuged at $1811 \mathrm{~g}$ for $10 \mathrm{~min}$ at $4^{\circ} \mathrm{C}$ (Eppendorf Centrifuge $5810 \mathrm{R}$; Eppendorf) and stored at $-20^{\circ} \mathrm{C}$ until analysis. Immediately after blood withdrawal, pigs were euthanised by an intracardiac injection of T61 $(10 \mathrm{ml} / \mathrm{kg}$, Embutramide; MSD Animal Health) and exsanguinated. The abdominal cavity was opened and the entire gastrointestinal tract was removed. For candidate gene expression, the mid-jejunum $(30 \mathrm{~cm}$ in the middle of the jejunum) and mid-colon (the middle of the colon after division into three equal segments) were selected as important intestinal sites for digestion and fermentation, respectively. Gut pieces were opened at the mesentery, and digesta were removed. Gut tissues were thoroughly washed in ice-cold PBS, and the mucosa was scraped off using a glass plate. Mucosa samples were immediately snap-frozen in liquid $\mathrm{N}_{2}$ and stored at $-80^{\circ} \mathrm{C}$.

\section{Gene expression profiling}

Total RNA was extracted and the mRNA expression in jejunal and colonic tissue were determined using quantitative 
reverse-transcription PCR, which has been described recently ${ }^{(19)}$. The amplification of target genes for sugar transporters (solute carrier family 2 (facilitated glucose transporter), member 2 (GLUT2) and solute carrier family 5 (sodium/glucose cotransporter), member 1 (SGLT1)), monocarboxylate transporters (monocarboxylate transporter 1 (MCT1) and sodium-coupled monocarboxylate transporter (SMCT)), tight junction proteins (occludin $(O C L N)$ and zonula occludens 1 (ZO1)), cytokines (IL1B, IL6, IL1O, interferon- $\gamma$ (INFG), TNFA and transforming growth factor- $\beta 1$ (TGFB1)) and pathogen-associated molecular patterns (toll-like receptor (TLR) 2 and TLR4) as well as housekeeping genes ( $\beta$-actin $(A C T B)$, hypoxanthine phosphoribosyltransferase 1 (HPRT1), glyceraldehyde 3-phosphate dehydrogenase $(G A P D H), \beta-2$ microglobulin $(B 2 M)$ and ornithine decarboxylase antizyme 1 (OAZ1); see online supplementary Table S1) were performed on a ViiA 7 Real-Time PCR system (Life Technologies). Reaction conditions for complementary DNA synthesis and quantitative PCR using the fluorescent DNA stain EvaGreen (Biotium) have been described elsewhere $^{(19)}$. Reverse transcription controls (RT minus) were included in order to control for residual DNA contamination, and experiments were performed in duplicates. Data were normalised to the expression of the three most suitable housekeeping genes ( $A C T B, G A P D H$ and $O A Z$ ), which were identified using the geNorm algorithm ${ }^{(22)}$. Relative gene expression were calculated using the $2^{-\Delta \Delta C_{t}} \operatorname{method}^{(23)}$

\section{Chemical analysis}

Before proximate analysis, faecal samples were thawed at $4{ }^{\circ} \mathrm{C}$ and homogenised per pig, and a subsample was taken for DM determination. The remaining faeces were freeze-dried. Diet and freeze-dried faeces were ground into a particle size of less than $1 \mathrm{~mm}$ before analysis. Chemical analyses of diets and faeces were performed using classical methods ${ }^{(24)}$ and commercial enzymatic kits, which have been described by Metzler-Zebeli et al. ${ }^{(17,19)}$. Porcine-specific commercial ELISA kits were used to analyse serum concentrations of the acutephase proteins haptoglobin and serum amyloid A (GenWay). Serum acute-phase proteins were selected on the basis of previously published data ${ }^{(25)}$. Ca and $\mathrm{P}$ in serum was determined by enzymatic colorimetric analysis using an autoanalyser for clinical chemistry (Cobas 6000/c501; Roche Diagnostics GmbH).

\section{Calculations}

The ATTD of nutrients was calculated as:

$$
\begin{aligned}
\operatorname{ATTD}(\%)= & ((\text { Daily nutrient intake }- \\
& \text { daily nutrient excretion in faeces }) / \\
& \text { daily nutrient intake }) \times 100 .
\end{aligned}
$$

Daily nutrient excretion in faeces was defined as the amounts of $\mathrm{Ca}, \mathrm{P}$ and $\mathrm{N}$ minerals present in the faeces and urine per d. Daily apparent retention was calculated as the difference between daily nutrient intake and daily nutrient excretion in faeces and urine.

\section{Statistical analyses}

To compare the differences between dietary Ca concentrations and cereals, data were subjected to ANOVA using the procedure PROC MIXED of SAS (Statistical Analysis System version 9.3; SAS Institute, Inc.). Fixed effects in the model included the main effects of Ca concentration, dietary cereal, their two-way interaction, the experimental run and the random effect of pig ( $n$ 31) nested within sow ( $n$ 16). The pig was considered the experimental unit. The KenwardRogers method was used to approximate $\mathrm{df}(\mathrm{ddfm}=\mathrm{kr})$. Data of mucosal gene expression collected from the same pig but at various gut sites were considered as spatial repeated measures using various variance-covariance matrix structures to take into consideration close associations among repeated measures. Gut site repeated measures and corresponding two-way and three-way interactions were analysed. Because there were significant gut site effects on the expression of all genes of interest, except TLR2 expression, gut sites were also individually analysed. Moreover, data on body weight, average daily gain and feed intake from the same pig but on different days of the experimental period were analysed using time-repeated measures and corresponding interactions. Means were reported as least squares means with their standard errors. Differences were considered significant at $P \leq 0.05$ and as trend at $0.05<P \leq 0.10$.

Linear discriminant analysis by JMP Pro (version 10.0; SAS Institute, Inc.) was applied to demonstrate potential relationships between diets and mucosal gene expression in the jejunum and colon using gene expression as the covariate and diet as the categorical variable. To illustrate the associations between colonic gene expression and mucusassociated bacteria and their metabolites, Spearman's rank correlation analysis was performed in JMP. For the relation between mucosal gene expression and mucus-associated bacteria, Spearman's rank correlation for the fifty most abundant operational taxonomic units (OTU) (published in Mann et $a l^{(17)}$ ) and gene expression were estimated. In Mann et $a l^{(18)}$, Roche/454-sequencing paired reads were analysed using the software package mothur ${ }^{(26)}$, and OTU were assigned based on a sequence similarity threshold of $97 \%$. Due to the short reads generated by Roche/454-sequencing, the cut-off of $97 \%$ was taken as a proxy for species-level divergence $^{(27)}$ so that the overall species diversity would not be overestimated, which might have been the case with a more stringent cut-off of 98 or $99 \%$. Obtained OTU were blasted against National Center for Biotechnology Information GenBank numbers to give an approximation of species classification (closest reference strains). Also, Spearman's rank correlations were computed for the relationships between colonic bacterial metabolites (published by Metzler-Zebeli et $a .^{(17)}$ ) and gene expression. SCFA concentrations in colonic digesta were analysed using GC, whereas lipopolysaccharides (LPS) were measured using a pyrochrome Limulus amebocyte lysate assay. The Limulus amebocyte lysate assay determines total LPS and does not differentiate between the LPS of different immune reactivities present in the sample. 


\section{Results}

\section{Dietary composition, feed intake and growth performance}

Chemical analyses showed that $\mathrm{Ca}$ concentrations were $0 \cdot 2-0 \cdot 3 \mathrm{~g} / \mathrm{kg}$ diet (DM basis) higher for adequate Ca diets and $0.3-1.0 \mathrm{~g} / \mathrm{kg}$ diet lower for high Ca diets as compared to the calculated dietary $\mathrm{Ca}$ concentration (Table 1). Consequently, actual dietary Ca concentrations corresponded to 103, 186, 104 and $176 \%$ of the $\mathrm{Ca}$ requirement of $10 \mathrm{~kg}$ pigs for the wheat-barley diet adequate in $\mathrm{Ca}$, the wheat-barley diet high in $\mathrm{Ca}$, the maize diet adequate in $\mathrm{Ca}$ and the maize diet high in $\mathrm{Ca}$, respectively. The $\mathrm{P}$ concentration of the maize diet adequate in $\mathrm{Ca}$ was $0.6 \mathrm{~g} \mathrm{P} / \mathrm{kg}$ diet (DM basis) higher, whereas the other three diets closely met the calculated $P$ values (Table 1). Thus, actual P concentrations corresponded to $98,195,108$ and $192 \%$ of the $P$ requirement of $10 \mathrm{~kg}$ pigs for the wheat-barley diet adequate in $\mathrm{Ca}$, the wheat-barley diet high in $\mathrm{Ca}$, the maize diet adequate in $\mathrm{Ca}$ and the maize diet high in $\mathrm{Ca}$, respectively. Dietary Ca:P ratios were 1.37:1, $1 \cdot 24: 1,1 \cdot 27: 1$ and $1 \cdot 21: 1$ for the wheat-barley diet adequate in $\mathrm{Ca}$, the wheat-barley diet high in $\mathrm{Ca}$, the maize diet adequate in $\mathrm{Ca}$ and the maize diet high in $\mathrm{Ca}$, respectively (Table 1). As indicated by the time $\times$ cereal interaction $(P=0.032)$, pigs that were fed the maize-based diets had a greater body weight and a $60 \mathrm{~g}$ higher average daily gain $(P<0.05)$ than pigs that were fed the wheat-barley-based diets, even though the daily feed intake was similar among the feeding groups (Table 2).

\section{Apparent total tract digestibility and nitrogen and mineral balances}

To establish the actual effect of dietary Ca concentration and cereal composition on digestive and absorptive processes, we determined the ATTD of DM, organic matter, protein, fat, ash, xylose, $\beta$-glucan, $\mathrm{Ca}$ and $\mathrm{P}$ as well as $\mathrm{Ca}, \mathrm{P}$ and $\mathrm{N}$ retention (Tables 3 and 4 ). When maize was the cereal source, pigs had a $1.5,5.5$ and $7.3 \%$ higher $(P<0.05)$ ATTD of DM, ash and $\mathrm{Ca}$, and they also tended to have greater $(P<0 \cdot 1)$ ATTD of organic matter and fat as compared to the pigs fed wheatbarley-based diets (Table 3). The dietary Ca concentration influenced the pigs' ATTD of DM and ash, resulting in 1.8 and $13 \%$ higher $(P<0.001)$ ATTD of DM and ash with the high and adequate $\mathrm{Ca}$ diets, respectively. The ATTD of protein
(Table 3), $\mathrm{N}$ intake, and faecal and urinary $\mathrm{N}$ excretion (Table 4) did not differ among the diets; however, daily $\mathrm{N}$ retention tended $(P=0.074)$ to be greater by $1.7 \mathrm{~g}$ in the pigs that were fed the maize diet as compared to the wheat-barley diet.

Daily Ca $(P<0 \cdot 001)$ and $\mathrm{P}(P<0 \cdot 001)$ intake was greater by 4 and $4.8 \mathrm{~g}$ with the high $\mathrm{Ca}$ diets as compared to the adequate Ca diets, respectively (Table 4). The pigs fed the high Ca diets excreted more $(P<0 \cdot 001) \mathrm{Ca}$ and $\mathrm{P}$ via faeces than those fed the adequate $C$ a diets, whereas only urinary $P$ excretion increased $(P<0.001)$ with the high Ca diets as compared to the adequate $\mathrm{Ca}$ diets. Although total daily absorption of $\mathrm{Ca}$ and $\mathrm{P}$ were higher with the high $\mathrm{Ca}$ diets as compared to the adequate $\mathrm{Ca}$ diets, high Ca diets slightly decreased $(P=0.037)$ the ATTD of Ca by $6.4 \%$ as compared to the adequate Ca diet (Table 3 ). The pigs fed the high Ca diets had a 2.7 and $2.3 \mathrm{~g}$ higher $(P<0 \cdot 001)$ total daily $\mathrm{Ca}$ and $\mathrm{P}$ retention than the pigs fed the adequate $\mathrm{Ca}$ diets, respectively (Table 4). The pigs fed maize diets had a $1.1 \mathrm{~g}$ higher $(P=0.009)$ Ca retention as compared to those fed the wheat-barley diets. Cereal source did not influence P retention, but $\mathrm{P}$ intake was $0.8 \mathrm{~g}$ higher $(P=0.042)$ in the pigs fed maize diets than it was in the pigs fed the wheat-barley diets.

\section{Serum parameters}

Acute-phase response was not stimulated by either dietary $\mathrm{Ca}$ concentration or cereal composition, as was indicated by the similar serum haptoglobin concentrations among the pigs and serum amyloid A concentrations that were below the detection limit (Table 3$)$. There was a cereal $\times \mathrm{Ca}$ interaction $(P=0.028)$, which shows that high $\mathrm{Ca}$ concentration reduced serum $\mathrm{Ca}$ concentration when it was added to the wheat-barley diets, whereas with maize diets, it increased the serum Ca concentration. Serum $\mathrm{P}$ concentration was raised $(P<0 \cdot 001)$ in the pigs fed the high $\mathrm{Ca}$ diets as compared to those fed adequate Ca diets, but the effect was smaller when pigs were fed the maize diets instead of the wheat-barley diets, as was indicated by the cereal $\times$ Ca interaction $(P=0 \cdot 049)$.

\section{Mucosal gene expression in the jejunum and colon}

Generally, mucosal expression of SGLT1, GLUT2, MCT1 and $S M C T$ was higher $(P<0.05)$ in the jejunum than in the colon (see online supplementary Table S2). Mucosal expression of

Table 2. Body weight, average daily feed intake (ADFI) and average daily gain (ADG) of weaned pigs fed wheat-barley or maize diets adequate or high in calcium

(Mean values with their standard errors; $n 8$ per diet, except wheat-barley diet high in calcium $n 7$ )

\begin{tabular}{|c|c|c|c|c|c|c|c|c|}
\hline & \multicolumn{2}{|c|}{ Wheat-barley diet } & \multicolumn{2}{|c|}{ Maize diet } & \multirow[b]{2}{*}{ SEM } & \multicolumn{3}{|c|}{$P$} \\
\hline & Adequate $\mathrm{Ca}$ & High Ca & Adequate $\mathrm{Ca}$ & High Ca & & Cereal & $\mathrm{Ca}$ & Cereal $\times \mathrm{Ca}$ \\
\hline \multicolumn{9}{|c|}{ Body weight $(\mathrm{kg})^{\star}$} \\
\hline Day 1 & 9.6 & 9.4 & $9 \cdot 6$ & 9.5 & 0.25 & 0.260 & 0.453 & 0.816 \\
\hline Day 15 & $16 \cdot 9$ & $16 \cdot 4$ & $18 \cdot 0$ & $17 \cdot 3$ & 0.51 & & & \\
\hline$A D G(g) \dagger$ & 488 & 466 & 559 & 518 & $23 \cdot 0$ & 0.013 & 0.189 & 0.696 \\
\hline ADFI (g)† & 679 & 631 & 725 & 702 & 37.4 & 0.132 & 0.357 & 0.737 \\
\hline
\end{tabular}

* Data on body weight were analysed using time-repeated measures over time, day $P<0.001$, time $\times$ Ca $P=0.282$, time $\times$ cereal $P=0.032$ and time $\times$ Ca $\times$ cereal $P=0.680$.

† Data on ADG and ADFI for experimental days 1-8 and 9-15 can be found in Metzler-Zebeli et al. ${ }^{(19)}$. Data on ADG and ADFI were analysed using time-repeated measures. 
Table 3. Apparent total tract digestibility (ATTD) of nutrients and serum haptoglobin, calcium and phosphorus concentration in weaned pigs fed wheat-barley or maize diets adequate or high in calcium

(Mean values with their standard errors; $n 8$ per diet, except wheat-barley diet high in calcium $n 7$ )

\begin{tabular}{|c|c|c|c|c|c|c|c|c|}
\hline & \multicolumn{2}{|c|}{ Wheat-barley diet } & \multicolumn{2}{|c|}{ Maize diet } & \multirow[b]{2}{*}{ SEM } & \multicolumn{3}{|c|}{$P$} \\
\hline & Adequate $\mathrm{Ca}$ & High Ca & Adequate $\mathrm{Ca}$ & High Ca & & Cereal & $\mathrm{Ca}$ & Cereal $\times \mathrm{Ca}$ \\
\hline \multicolumn{9}{|l|}{ ATTD (\%) } \\
\hline DM & 86.5 & 87.7 & 87.4 & 89.9 & 0.66 & 0.027 & 0.009 & 0.348 \\
\hline Organic matter & 88.4 & 88.2 & 88.7 & 90.4 & 0.67 & 0.074 & 0.290 & 0.144 \\
\hline Ash & $59 \cdot 0$ & 73.5 & $65 \cdot 8$ & $78 \cdot 2$ & 1.73 & 0.003 & $<0.001$ & 0.550 \\
\hline Fat & $69 \cdot 3$ & 73.9 & 74.4 & $75 \cdot 0$ & 1.66 & 0.077 & 0.136 & 0.242 \\
\hline Protein & $86 \cdot 0$ & $85 \cdot 2$ & $86 \cdot 1$ & 87.4 & 0.87 & 0.195 & 0.766 & 0.231 \\
\hline Xylose & $44 \cdot 8$ & $52 \cdot 1$ & 31.0 & 36.5 & 8.74 & 0.104 & 0.472 & 0.919 \\
\hline$\beta$-Glucan & $97 \cdot 4$ & 97.6 & $97 \cdot 0$ & $92 \cdot 8$ & 1.76 & 0.152 & 0.262 & 0.232 \\
\hline $\mathrm{Ca}$ & $73 \cdot 2$ & $67 \cdot 4$ & $80 \cdot 5$ & 73.5 & $2 \cdot 90$ & 0.031 & 0.037 & 0.831 \\
\hline $\mathrm{P}$ & $72 \cdot 9$ & $76 \cdot 7$ & $77 \cdot 0$ & $77 \cdot 8$ & 1.58 & 0.116 & 0.152 & 0.355 \\
\hline Serum haptoglobin (mg/l) & 246 & 226 & 205 & 204 & $86 \cdot 3$ & 0.721 & 0.904 & 0.914 \\
\hline Serum $\mathrm{Ca}(\mathrm{mmol} / \mathrm{l})$ & $3 \cdot 1^{\mathrm{a}}$ & $2 \cdot 9^{a, b}$ & $2 \cdot 8^{\mathrm{b}}$ & $2 \cdot 9^{a, b}$ & 0.07 & 0.170 & 0.300 & 0.028 \\
\hline Serum $P(\mathrm{mmol} / \mathrm{l})$ & $1.9^{\mathrm{b}}$ & $2 \cdot 8^{\mathrm{a}}$ & $2 \cdot 5^{a, b}$ & $2.9^{\mathrm{a}}$ & 0.13 & 0.009 & $<0.001$ & 0.049 \\
\hline
\end{tabular}

${ }^{\mathrm{a}, \mathrm{b}}$ Mean values within a row with unlike superscript letters were significantly different $(P<0.05)$.

$Z O 1$ was higher in the jejunum than in the colon, whereas that of $O C L N$ was lower in the jejunum than in the colon $(P<0.05$; see online supplementary Table S2). Except for TLR4 and the cytokines IL1O and INFG, whose mucosal expression showed the opposite effect, the expression of $I L 1 B, I L 6$ and TGFB1 $(P<0.05)$ as well as that of TNFA $(P<0 \cdot 1)$ was higher in the colon than in the jejunum (see online supplementary Table S2). Mucosal expression of TLR2 was similar in jejunal and colonic tissue. The principal effects of differences in dietary Ca intake occurred on the jejunal expression of tight junction proteins and TLR2. Expression of $O C L N(P<0.031)$ and $Z O 1$ $(P<0.044)$ was down-regulated in the jejunal mucosa of the pigs fed the high $\mathrm{Ca}$ diets as compared to those fed the adequate Ca diets (Fig. 1(a) and (b)). Mucosal expression of
TLR2, in turn, was up-regulated $(P<0 \cdot 016)$ in the jejunum of the pigs fed the high $\mathrm{Ca}$ diets and was three to four times higher than that of the pigs fed the adequate $\mathrm{Ca}$ diets (Table 5). Also, the basal diet affected TLR2 expression; there was greater $(P<0.039)$ TLR2 expression in the jejunal mucosa of the pigs fed the wheat-barley diets as compared to those fed the maize diets. There was a tendency for a $\mathrm{Ca} \times$ cereal interaction $(P<0.092)$ for $I N F G$ expression, indicating that with the wheat-barley diet, high Ca concentration down-regulated jejunal INFG expression, whereas high $\mathrm{Ca}$ concentration up-regulated its expression with the maize diets. Dietary Ca concentration and basal diet did not affect sugar and monocarboxylate transporter expression in the jejunal mucosa of the pigs, whereas there was a trend $(P=0.076)$

Table 4. Nitrogen, calcium and phosphorus balances in weaned pigs fed wheat-barley or maize diets adequate or high in calcium (Mean values with their standard errors; $n 8$ per diet, except wheat-barley diet high in calcium $n 7$ )

\begin{tabular}{|c|c|c|c|c|c|c|c|c|}
\hline & \multicolumn{2}{|c|}{ Wheat-barley diet } & \multicolumn{2}{|c|}{ Maize diet } & \multirow[b]{2}{*}{ SEM } & \multicolumn{3}{|c|}{$P$} \\
\hline & Adequate $\mathrm{Ca}$ & High Ca & Adequate $\mathrm{Ca}$ & High Ca & & Cereal & $\mathrm{Ca}$ & Cereal $\times \mathrm{Ca}$ \\
\hline \multicolumn{9}{|l|}{$\mathrm{N}$ balance $(\mathrm{g} / \mathrm{d})$} \\
\hline $\mathrm{N}$ intake & $29 \cdot 2$ & $26 \cdot 8$ & $29 \cdot 3$ & $29 \cdot 6$ & $1 \cdot 26$ & $0 \cdot 268$ & 0.405 & 0.268 \\
\hline Faecal $\mathrm{N}$ excretion & $4 \cdot 1$ & $4 \cdot 0$ & $4 \cdot 1$ & $3 \cdot 8$ & 0.29 & 0.633 & 0.483 & 0.760 \\
\hline Urinary $\mathrm{N}$ excretion & $4 \cdot 3$ & $4 \cdot 1$ & $3 \cdot 8$ & $4 \cdot 3$ & 0.34 & 0.667 & 0.707 & 0.291 \\
\hline Total N excretion & $8 \cdot 4$ & $8 \cdot 1$ & $7 \cdot 9$ & $8 \cdot 1$ & 0.54 & 0.597 & 0.884 & 0.615 \\
\hline $\mathrm{N}$ absorption & $25 \cdot 2$ & $25 \cdot 2$ & $22 \cdot 8$ & $25 \cdot 2$ & $1 \cdot 12$ & 0.175 & 0.449 & 0.201 \\
\hline $\mathrm{N}$ retention & $20 \cdot 8$ & $18 \cdot 7$ & $21 \cdot 4$ & $21 \cdot 5$ & 0.91 & 0.074 & 0.291 & 0.239 \\
\hline \multicolumn{9}{|l|}{ Ca balance $(g / d)$} \\
\hline Ca intake & $6 \cdot 8$ & $10 \cdot 9$ & $7 \cdot 0$ & $12 \cdot 0$ & 0.43 & 0.142 & $<0.001$ & 0.301 \\
\hline Faecal Ca excretion & 1.8 & 3.6 & 1.4 & $3 \cdot 2$ & 0.35 & 0.296 & $<0.001$ & 0.917 \\
\hline Urinary $\mathrm{Ca}$ excretion & 0.59 & 0.44 & 0.40 & 0.49 & 0.12 & 0.555 & 0.834 & 0.318 \\
\hline Total Ca excretion & $2 \cdot 4$ & $4 \cdot 0$ & $1 \cdot 8$ & 3.7 & 0.39 & 0.269 & $<0.001$ & 0.695 \\
\hline Ca absorption & $5 \cdot 0$ & $7 \cdot 3$ & $5 \cdot 6$ & $8 \cdot 7$ & 0.38 & 0.013 & $<0.001$ & 0.282 \\
\hline Ca retention & 4.4 & $6 \cdot 8$ & $5 \cdot 2$ & $8 \cdot 2$ & 0.39 & 0.009 & $<0.001$ & 0.450 \\
\hline \multicolumn{9}{|l|}{$P$ balance $(g / d)$} \\
\hline $\mathrm{P}$ intake & $5 \cdot 0$ & $9 \cdot 0$ & $5 \cdot 4$ & $10 \cdot 0$ & 0.33 & 0.042 & $<0.001$ & 0.458 \\
\hline Faecal P excretion & $1 \cdot 3$ & $2 \cdot 1$ & $1 \cdot 2$ & $2 \cdot 2$ & 0.14 & 0.804 & $<0.001$ & 0.444 \\
\hline Urinary $\mathrm{P}$ excretion & 0.12 & $1 \cdot 21$ & 0.12 & $1 \cdot 37$ & 0.21 & 0.683 & $<0.001$ & 0.698 \\
\hline Total P excretion & 1.4 & $3 \cdot 3$ & $1 \cdot 4$ & $3 \cdot 6$ & 0.23 & 0.600 & $<0.001$ & 0.403 \\
\hline P absorption & $3 \cdot 6$ & 6.9 & $4 \cdot 2$ & $7 \cdot 7$ & 0.29 & 0.028 & $<0.001$ & 0.640 \\
\hline $\mathrm{P}$ retention & 3.5 & $5 \cdot 7$ & $4 \cdot 1$ & $6 \cdot 4$ & 0.32 & $0 \cdot 820$ & $<0.001$ & 0.868 \\
\hline
\end{tabular}



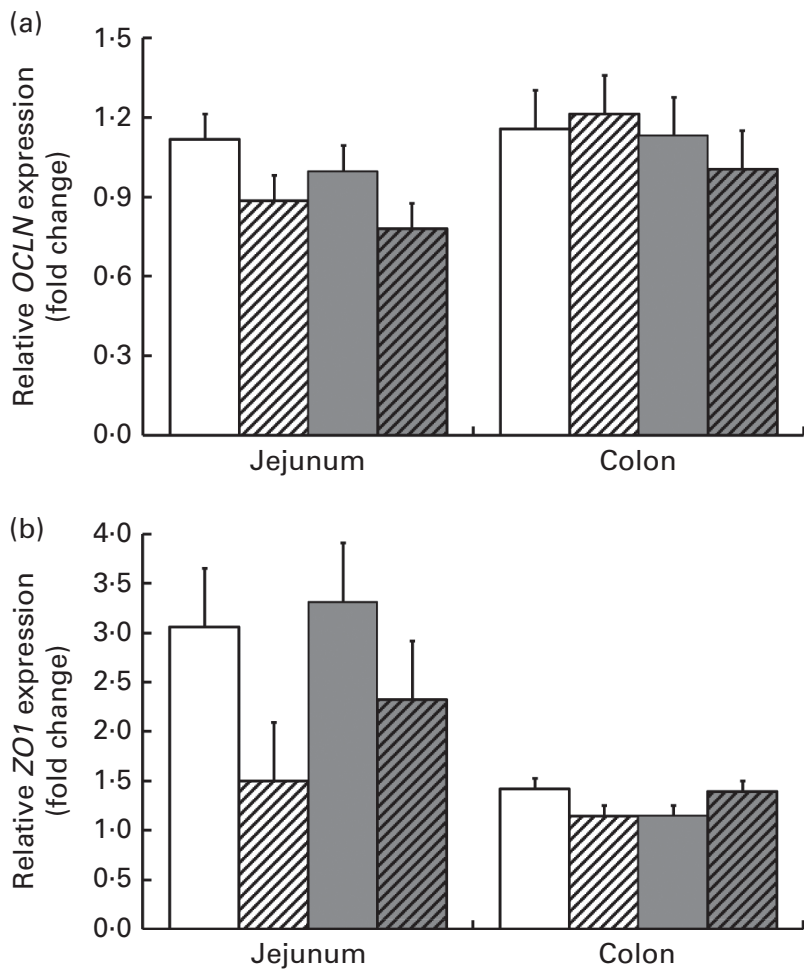

Fig. 1. Relative expression of (a) occludin $(O C L M)$ and (b) zonula occludens 1 (ZO1) in the jejunal and colonic mucosa of weaned pigs fed wheat-barley or maize diets adequate or high in $\mathrm{Ca}$. Values are means with their standard errors; $n 8$ per diet, except wheat-barley diet high in calcium $n 7$, are represented by vertical bars. (a) Main effects on OCLN expression: jejunum, calcium $P=0.031$, cereal $P=0.269$, calcium $\times$ cereal $P=0.0 .942$; colon, calcium $P=0.816$, cereal $P=0.443$, calcium $\times$ cereal $P=0.543$; gut site effect $P=0.028$, gut site $\times$ calcium $P=0.509$, gut site $\times$ cereal $P=0.443$, gut site $\times$ calcium $\times$ cereal $P=0.843$. (b) Main effects on $Z O 1$ expression: jejunum, calcium $P=0.044$, cereal $P=0.371$, calcium $\times$ cereal $P=0.638$; colon, calcium $P=0.884$, cereal $P=0.921$, calcium $\times$ cereal $P=0.950$, gut site $P<0.001$, gut site $\times$ calcium $P=0.028$, gut site $\times$ cereal $P=0.341$, gut site $\times$ calcium $\times$ cereal $P=0.619$. $\square$, wheat-barley diet adequate in calcium $\square$, wheat-barley diet high in calcium; $\square$, maize diet adequate in calcium; a, maize diet high in calcium.

for a down-regulation of SMCT expression in the colonic mucosa of the pigs fed the high Ca diets as compared to those fed the adequate $\mathrm{Ca}$ diets (Table 6). As indicated by the $\mathrm{Ca} \times$ cereal interaction $(P=0.021)$, the mucosal $I L 1 B$ expression responded differently to the dietary Ca concentration depending on the cereal source fed to the pigs. Mucosal $I L 1 B$ expression was up-regulated by high Ca concentration when combined with a wheat-barley diet, but it was down-regulated when combined with a maize diet as compared to the respective adequate Ca diets. There was a gut site $\times \mathrm{Ca}$ interaction $(P<0.028)$ for $Z O 1$ expression, which indicates that $Z O 1$ expression was down-regulated by high $\mathrm{Ca}$ diets in the jejunum but not in the colon (Fig. 1), although no further gut site $\times \mathrm{Ca}$, gut site $\times$ cereal or gut site $\times$ $\mathrm{Ca} \times$ cereal interaction could be found for the expression of the other target genes (data not shown).

The linear discriminant analysis of diets and mucosal gene expression in the jejunum (Fig. 2(a)) and the colon (Fig. 2(b)) showed that diet modulated mucosal gene expression and separated the effects of the diets into two and four clusters, respectively. In the jejunum, diets clustered completely separately from one other. The jejunal expression of TLR2, TNFA, INFG, TGFB1 and OCLN discriminated best for the wheat-barley diet with adequate Ca concentration, whereas the expression of TLR 4 and SMCT was more associated with the wheat-barley diet high in $\mathrm{Ca}$. The maize diet adequate in $\mathrm{Ca}$, in turn, correlated to jejunal $I L 1 B$ expression, and the maize diet high in $\mathrm{Ca}$ correlated to the jejunal expression of MCT1, GLUT2, SGLT1, IL1O, IL6 and ZO1. In the colon, the wheat-barley diet adequate in Ca clustered separately, whereas the other three diets formed one cluster according to their overlapping 95\% CI. In the colon, the wheat-barley diet adequate in Ca was clearly related to the mucosal expression of TGFB1, which distinguishes it from the other three diets.

\section{Spearman's rank correlations between bacteria and mucosal candicate gene expression in the colon}

To identify potential associations between the mucosaattached bacteria, microbial metabolites and mucosal gene expression in the colon, we performed Spearman's rank correlation. Only Spearman's rank correlation coefficients showing a significant correlation are presented (Tables 7 and 8). Correlations ranged from $r \pm 0.36$ to \pm 0.62 , and correlations were stronger for microbial metabolites. Out of the fifty most abundant OTU, twelve mucosa-associated OTU positively or negatively correlated to the colonic expression of sugar and monocarboxylate transporters, cytokines, pathogenrecognition receptors and tight junction proteins (Table 7). Microbial metabolites (SCFA and LPS) positively or negatively correlated with the colonic expression of cytokines, TLR and GLUT2 (Table 8).

\section{Discussion}

The present results demonstrated that dietary Ca concentration modified the jejunal expression of genes related to mucosal permeability and pathogen-associated molecular patterns in young barrows. In addition, dietary cereal composition appeared to interact with the Ca effects on mucosal gene expression response, as was indicated by the distinguishable patterns exhibited by the two $\mathrm{Ca}$ concentrations and basal diets in the linear discriminant analysis scores plots, particularly for the jejunum, and as was indicated by the observed $\mathrm{Ca} \times$ cereals interactions. Correlation coefficients substantiated the link between mucosa-associated bacteria and microbial metabolites and colonic gene expression response. Because we tried to keep the dietary Ca:P ratio similar between the four experimental diets, the effects of $\mathrm{Ca}$ and $\mathrm{P}$ cannot be seen separately in the present study. Moreover, we would like to point out that we used castrated male pigs, and results obtained in the present study thus might not be totally transferable to young female pigs or intact males, as the $\mathrm{P}$ requirements of pigs between 10 and $20 \mathrm{~kg}$ differ between the sexes ${ }^{(21,28)}$.

To explore the potential $\mathrm{Ca}$ effects on digestion and mucosal response in the small and large intestines of young pigs, it was critical to maintain contrasting $\mathrm{Ca}$ and $\mathrm{P}$ concentrations 
Table 5. Relative expression of cytokines and pathogen-recognition receptors in jejunal and colonic mucosa of weaned pigs fed wheat-barley or maize diets adequate or high in calcium

(Mean values with their standard errors; $n 8$ per diet, except wheat-barley diet high in calcium $n 7$ )

\begin{tabular}{|c|c|c|c|c|c|c|c|c|}
\hline & \multicolumn{2}{|c|}{ Wheat-barley diet } & \multicolumn{2}{|c|}{ Maize diet } & \multirow[b]{2}{*}{ SEM } & \multicolumn{3}{|c|}{$P$} \\
\hline & Adequate $\mathrm{Ca}$ & High Ca & Adequate $\mathrm{Ca}$ & High $\mathrm{Ca}$ & & Cereal & $\mathrm{Ca}$ & Cereal $\times \mathrm{Ca}$ \\
\hline \multicolumn{9}{|l|}{ Jejunum } \\
\hline$I L 1 B$ & 0.85 & 0.74 & 0.77 & 0.78 & $0 \cdot 101$ & 0.879 & 0.628 & 0.580 \\
\hline IL6 & 0.39 & 0.42 & 0.52 & 0.43 & 0.112 & 0.533 & 0.766 & 0.604 \\
\hline IL10 & 2.63 & $2 \cdot 88$ & $2 \cdot 14$ & $2 \cdot 36$ & 0.388 & 0.197 & 0.560 & 0.974 \\
\hline INFG & $3.37^{\mathrm{a}}$ & $2 \cdot 24^{b}$ & $1 \cdot 82^{b}$ & $2 \cdot 80^{a, b}$ & 1.581 & 0.396 & 0.899 & 0.092 \\
\hline$T N F A$ & $1 \cdot 31$ & 1.24 & 1.59 & 1.56 & 0.298 & 0.320 & 0.868 & 0.937 \\
\hline TGFB1 & 0.92 & 0.73 & 1.05 & 1.01 & 0.270 & 0.464 & 0.669 & 0.768 \\
\hline TLR2 & 0.88 & 3.33 & 0.43 & 1.22 & 0.582 & 0.039 & 0.016 & 0.172 \\
\hline TLR4 & 1.98 & $2 \cdot 70$ & $1 \cdot 76$ & 1.97 & 0.374 & 0.211 & 0.228 & 0.510 \\
\hline \multicolumn{9}{|l|}{ Colon } \\
\hline IL1B & $2 \cdot 73^{b}$ & $5.95^{\mathrm{a}}$ & $3.99^{a, b}$ & $3.30^{\mathrm{b}}$ & 0.793 & 0.390 & 0.123 & 0.021 \\
\hline ILG & 1.72 & 1.93 & $2 \cdot 20$ & 1.97 & 0.249 & 0.297 & 0.965 & 0.381 \\
\hline IL 10 & 1.40 & 1.69 & 1.87 & 1.64 & 0.178 & 0.244 & 0.862 & 0.157 \\
\hline$I N F G$ & 0.98 & 1.51 & 1.06 & 1.31 & 0.311 & 0.844 & 0.222 & 0.671 \\
\hline$T N F A$ & 1.86 & 1.96 & $2 \cdot 31$ & 1.64 & 0.261 & 0.815 & 0.285 & 0.153 \\
\hline TGFB1 & 1.43 & 1.47 & 1.65 & $1 \cdot 30$ & 0.135 & 0.868 & 0.252 & 0.156 \\
\hline$T L R 2$ & $1 \cdot 21$ & 1.69 & 1.31 & 1.46 & 0.202 & 0.735 & 0.130 & 0.423 \\
\hline TLR4 & 1.35 & 1.55 & 1.60 & 1.48 & 0.157 & 0.559 & 0.802 & 0.318 \\
\hline
\end{tabular}

INFG, interferon- $\gamma$; TGFB1, transforming growth factor- $\beta 1 ; T L R$, toll-like receptor.

${ }^{a, b}$ Mean values within a row with unlike superscript letters were significantly different $(P<0.05)$

along the gastrointestinal tract with the two dietary concentrations of $\mathrm{Ca}$ and, as a consequence, also of $\mathrm{P}$, and according to the results of the faecal excretion of $\mathrm{Ca}$ and $\mathrm{P}$, we were successful in doing so. Both elements are necessary for the formation of the Ca-phosphate complex in the intestinal lumen $^{(5)}$. In rats, the beneficial cytoprotective effects of high $\mathrm{Ca}$ diets in the intestinal lumen have been principally linked to the buffering properties of this Ca-phosphate complex, and the colon has been identified as the main intestinal site that responds to $\mathrm{Ca}$ action ${ }^{(4,5)}$. In line with our previous study ${ }^{(9)}$, the intestinal site where we observed a stronger Ca effect on mucosal gene expression was the small intestine; fewer $\mathrm{Ca}$ effects were visible for the colonic mucosa. In contrast to our assumption that high dietary $\mathrm{Ca}$ intake would up-regulate the expression of genes related to mucosal barrier function, we found a substantial down-regulation of $O C L N$ and ZO1 expression in the jejunum with the high $\mathrm{Ca}$ diets as compared to the adequate $\mathrm{Ca}$ diets, whereas the expression of OCLN and ZO1 in the colon was unaffected by the dietary $\mathrm{Ca}$ concentration. Bearing in mind the potential translational modification of mRNA, findings of a downregulation in the expression of genes that encode for tight junction proteins in the jejunum might be counterproductive in the juvenile phase, given that proper barrier function has been suggested as a key mechanism for the development of intestinal disease ${ }^{(29)}$. However, we did not see an enhanced serum acute-phase response or intestinal translocation of LPS $^{(17)}$, which would have been a sign of higher intestinal

Table 6. Relative expression of nutrient transporters related to sugar and fermentation acid absorption in the jejunum and the colon of weaned pigs fed wheat-barley or maize diets adequate or high in calcium

(Mean values with their standard errors; $n 8$ per diet, except wheat-barley diet high in calcium $n 7$ )

\begin{tabular}{|c|c|c|c|c|c|c|c|c|}
\hline & \multicolumn{2}{|c|}{ Wheat-barley diet } & \multicolumn{2}{|c|}{ Maize diet } & \multirow[b]{2}{*}{ SEM } & \multicolumn{3}{|c|}{$P$} \\
\hline & Adequate $\mathrm{Ca}$ & High $\mathrm{Ca}$ & Adequate $\mathrm{Ca}$ & High $\mathrm{Ca}$ & & Cereal & $\mathrm{Ca}$ & Cereal $\times \mathrm{Ca}$ \\
\hline \multicolumn{9}{|l|}{ Jejunum } \\
\hline GLUT2 & 0.96 & 0.93 & $1 \cdot 14$ & 1.06 & 0.135 & $0 \cdot 271$ & 0.705 & 0.866 \\
\hline SGLT1 & $7 \cdot 21$ & $7 \cdot 79$ & 8.43 & $8 \cdot 71$ & $1 \cdot 305$ & 0.421 & 0.740 & 0.910 \\
\hline MCT1 & 1.50 & $1 \cdot 31$ & $1 \cdot 23$ & $1 \cdot 70$ & 0.355 & 0.876 & 0.696 & 0.363 \\
\hline SMCT & 1.06 & $1 \cdot 36$ & $1 \cdot 11$ & $1 \cdot 26$ & 0.168 & 0.885 & 0.186 & 0.647 \\
\hline \multicolumn{9}{|l|}{ Colon } \\
\hline GLUT2 & 0.07 & 0.09 & 0.21 & 0.03 & 0.061 & 0.206 & 0.475 & 0.130 \\
\hline SGLT1 & $1 \cdot 10$ & 0.94 & 1.08 & 0.94 & 0.096 & 0.884 & 0.131 & 0.928 \\
\hline MCT1 & 1.00 & 0.82 & 0.77 & 0.92 & 0.098 & 0.556 & 0.878 & 0.108 \\
\hline SMCT & $1 \cdot 16$ & 0.95 & 1.08 & 0.94 & 0.507 & 0.631 & 0.076 & 0.722 \\
\hline
\end{tabular}

GLUT2, solute carrier family 2 (facilitated glucose transporter), member 2; SGLT1, solute carrier family 5 (sodium/glucose cotransporter), member 1; MCT1, monocarboxylate transporter 1; SMCT, sodium-coupled monocarboxylate transporter. 

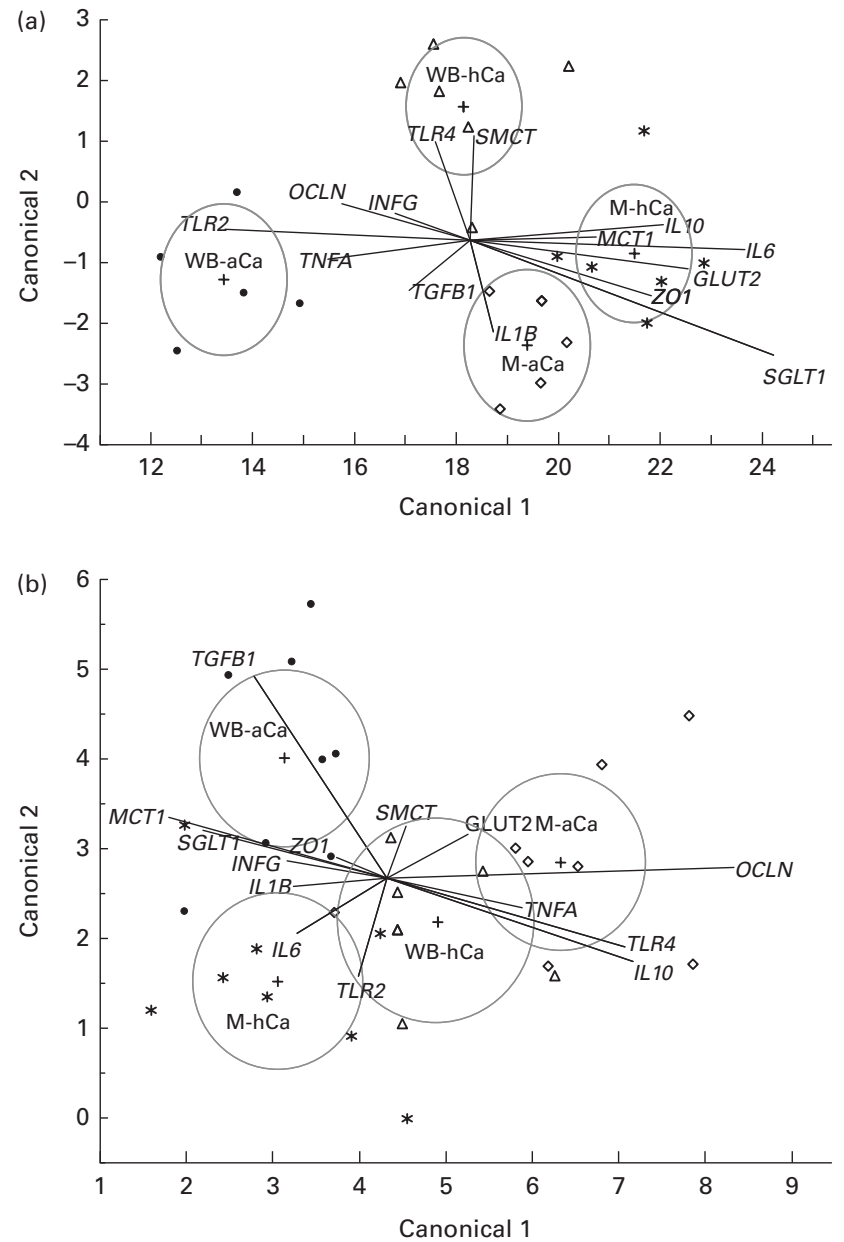

Fig. 2. Linear discriminant analysis of the wheat-barley and maize diets adequate or high in calcium and data of gene expression in (a) the jejunum and (b) the colon of weaned pigs ( $n$ 31). $\bullet$, Wheat-barley diet adequate in calcium (WB-aCa); $\Delta$, wheat-barley diet high in calcium (WB-hCa); $\diamond$, maize diet adequate in calcium $(\mathrm{M}-\mathrm{aCa}) ; *$, maize diet high in calcium $(\mathrm{M}-\mathrm{hCa}) ;+$, treatment mean. Circles indicate $95 \%$ confidence intervals. TLR, toll-like receptor; OCLN, occludin; INFG, interferon- $\gamma$; SMCT, sodium-coupled monocarboxylate transporter; TGFB1, transforming growth factor- $\beta$ 1; MCT1, monocarboxylate transporter 1; GLUT2, solute carrier family 2 (facilitated glucose transporter), member 2; ZO1, zonula occludens 1 ; SGLT1, solute carrier family 5 (sodium/glucose cotransporter), member 1.

permeability. Thus, it is possible that alterations in gene expression were not translated into functional protein. We did not scrutinise $\mathrm{Ca}$ absorptive pathways in the present study; however, the down-regulation in the expression of $Z O 1$ and OCLN also may have been related to the intestinal availability and absorption of $\mathrm{Ca}^{(30-32)}$. In pigs, the main site of active $\mathrm{Ca}$ absorption is the proximal small intestine ${ }^{(33)}$. Transport proteins expression at the apical site of the enterocyte strongly regulates active transcellular $\mathrm{Ca}$ uptake, which is adjusted to luminal $\mathrm{Ca}$ availability ${ }^{(33,34)}$. The latter has also been proposed to influence the rate of paracellular Ca transport by modifying the gene expression of tight junction proteins which form paracellular channels for selective ion transfer between neighbouring epithelial cells in the small intestine ${ }^{(31,32,35)}$. Evidence is growing for the cooperative functioning of active and passive $\mathrm{Ca}$ transport pathways via the regulation of the expression of tight junction proteins by transcellular calbindin- $\mathrm{D}_{9 \mathrm{~K}}$ protein expression ${ }^{(32)}$. Diets high in $\mathrm{Ca}$ were reported to reduce active transcellular $\mathrm{Ca}$ uptake via the down-regulation of membrane $\mathrm{Ca}$ channels and calbindin proteins expression in the upper small intestine $^{(35)}$. Further studies should therefore look more closely at the link between intestinal transcellular and paracellular $\mathrm{Ca}$ transfer pathways in juvenile animals, such as weaned pigs, and explore whether there is an association between the regulation of paracellular $\mathrm{Ca}$ transport and the barrier function of the intestinal mucosa, thereby focusing not only on gene expression but also on functional protein expression.

Intestinal monocarboxylate transporters expression is substrate induced ${ }^{(36,37)}$. Therefore, lower substrate availability due to the binding of SCFA to Ca-phosphate may explain the down-regulated expression of SMCT in the colonic mucosa of the pigs fed the high $\mathrm{Ca}$ diets as compared to those fed the adequate $\mathrm{Ca}$ diets. Colonic SCFA concentrations were not altered by dietary $\mathrm{Ca}$ concentration ${ }^{(17)}$. The present findings are in line with the trend of a lower ileal MCT1 expression which was recently observed in weaned pigs fed high $\mathrm{Ca}$ diets as compared to those fed low $\mathrm{Ca}$ diets ${ }^{(9)}$. The beneficial cytoprotective effects of high $\mathrm{Ca}$ diets, such as the down-regulation of pro-inflammatory cytokine expression, which have been suggested by previous studies in rats $^{(3,4)}$ and weaned pigs ${ }^{(9)}$ were not as clearly visible. However, present findings demonstrated that the cereal composition of the diet interacted with the $\mathrm{Ca}$ effect on the mucosal expression of pro-inflammatory cytokines, as indicated by the jejunal INFG expression and colonic $I L 1 B$ expression. In previous research in rodents $^{(3,4,8)}$ and weaned pigs ${ }^{(9)}$, animals were fed semi-purified diets based on purified starch and casein. Thus, interactions between dietary $\mathrm{Ca} \times$ composition of the basal diet (corn starch-casein diets $v$. cereal-soyabean meal-based diets) may explain the diverging mucosal gene expression responses between previous studies and the present experiment. Moreover, differences in the dietary $\mathrm{Ca}$ and $\mathrm{P}$ concentrations may have also played a role in the varying results between the present and previous studies ${ }^{(4,8,9)}$ For instance, in our earlier study in weaned pigs, dietary $\mathrm{Ca}$ concentrations were lower compared to those in the present study; they corresponded to 60 and $125 \%$ of the daily $\mathrm{Ca}$ requirement, respectively ${ }^{(9)}$

High Ca diets improved the ATTD of DM, which may be mostly a result of improved ash digestibility, as indicated by the similar ATTD of organic matter as compared to adequate Ca diets. Maize, wheat and barley differ in their major nutrient fractions (i.e. carbohydrates, dietary fibre, proteins and fat), which leads to differences in their major nutrient digestibilities $^{(38,39)}$ and systemic nutrient metabolism ${ }^{(19)}$. The higher ATTD of DM and $\mathrm{N}$ retention was therefore very likely the reason for the enhanced growth of the pigs fed the maize diets as compared to the pigs fed the wheat-barley diets. Despite the fact that dietary fat concentration was small, it is possible that diverging fatty acid profiles caused by the different dietary fat origins may have influenced the digestibility of $\mathrm{Ca}$, because dietary $\mathrm{Ca}$ forms insoluble $\mathrm{Ca}$ soaps with fatty 
Table 7. Spearman's correlation coefficients for colonic gene expression and mucosa-associated bacterial operational taxonomic units (OTU) in the colon of pigs fed wheat-barley or maize diets adequate or high in calcium

\begin{tabular}{lllrr}
\hline & Closest reference strain (GenBank accession no.) ${ }^{*}$ & Gene & \multicolumn{1}{c}{$r$} & $P$ \\
\hline OTU 1 & Lactobacillus johnsonii (JN012223) & SMCT & -0.36 & 0.050 \\
OTU 2 & Lactobacillus amylovorus (EF120375) & SMCT & 0.36 & 0.049 \\
OTU 3 & Lactobacillus mucosae (AB425938) & IL1B & -0.39 & 0.034 \\
OTU 3 & Lactobacillus mucosae (AB425938) & TGFB1 & -0.56 & 0.001 \\
OTU 3 & Lactobacillus mucosae (AB425938) & TNFA & -0.46 & 0.011 \\
OTU 4 & Lactobacillus delbrueckii (AB680073) & TGFB1 & -0.37 & 0.046 \\
OTU 5 & Prevotella copri (AB649279) & ZO1 & 0.37 & 0.043 \\
OTU 8 & Prevotella copri (AB649279) & SGLT1 & -0.52 & 0.003 \\
OTU 18 & Prevotella copri (NR_040877) & TLR2 & -0.41 & 0.026 \\
OTU 27 & Lachnospiraceae bacterium DJF_RR61 (EU728764) & MCT1 & -0.42 & 0.022 \\
OTU 27 & Lachnospiraceae bacterium DJF_RR61 (EU728764) & SMCT & -0.44 & 0.015 \\
OTU 89 & Eubacterium sp. F1 (EU281854) & SMCT & 0.38 & 0.037 \\
OTU 155 & Prevotellaceae bacterium DJF_VR15 (EU728784) & TLR2 & -0.38 & 0.043 \\
OTU 351 & Helicobacter rappini (AY034817) & OCLN & -0.38 & 0.038 \\
OTU 351 & Helicobacter rappini (AY034817) & ZO1 & -0.37 & 0.045 \\
OTU 624 & Campylobacter lanienae (JX912520) & TGFB1 & 0.52 & 0.003 \\
OTU 624 & Campylobacter lanienae (JX912520) & TNFA & 0.47 & 0.009 \\
OTU 2498 & Prevotella ruminicola (AF218618) & TGFB1 & 0.46 & 0.012 \\
\hline
\end{tabular}

$S M C T$, sodium-coupled monocarboxylate transporter; TGFB1, transforming growth factor- $\beta 1$; ZO1, zonula occludens 1; SGLT1, solute carrier family 5 (sodium/glucose cotransporter), member 1; TLR2, toll-like receptor 2; MCT1, monocarboxylate transporter 1; OCLN, occludin.

* Mucosa-associated OTU are published in Mann et al. ${ }^{(18)}$ and were blasted against National Center for Biotechnology Information GenBank numbers. A sequence similarity of $97 \%$ was used as a cut-off for assigning sequences to OTU.

acids in the small intestine ${ }^{(2,40)}$. Likewise, the diverging hemicellulose and cellulose profiles of the maize $v$. wheat-barley diets might have altered $\mathrm{Ca}$ and $\mathrm{P}$ absorption because of changes in intestinal digesta viscosity or the complexing of Ca by complex carbohydrates ${ }^{(41-43)}$. Furthermore, wheatbarley and maize diets differ in their digestible and resistant starch fractions ${ }^{(17)}$, which could change the jejunal expression of the apical and baso-lateral sugar transporters SGLT1 and GLUT2, respectively, but this was not the case in the present study. Instead, the colonic expression of GLUT2 was downregulated by the high $v$. adequate $\mathrm{Ca}$ concentration but only in the pigs fed maize diets. Overall, we could not find dietary $\mathrm{Ca} \times$ cereal interactions for indirect estimates of digestion and absorption, which suggests that Ca effects were similarly directed by, and hence mostly independent of, the cereal composition of the basal diet.

A noteworthy observation of the present study was that the $\mathrm{Ca}$ and $\mathrm{P}$ balance data suggested that the wheat-barley diet adequate in $\mathrm{Ca}$ did not contain sufficient amounts of available $P$. This was particularly visible when comparing the results for urinary excretion and retention from the pigs fed the wheat-barley diet adequate in $\mathrm{Ca}$ with those fed the wheat-barley diet high in $\mathrm{Ca}$. It indicates that the absorbed dietary Ca could not be sufficiently used by the pigs fed the wheat-barley diet adequate in Ca. The pigs fed the wheatbarley diets adequate in $\mathrm{Ca}$ excreted more $\mathrm{Ca}$ via urine than the pigs fed the corresponding diet high in $\mathrm{Ca}$, although it should have been vice versa. Likewise, $\mathrm{P}$ retention increased more than $\mathrm{Ca}$ retention in the pigs fed the wheat-barley diet adequate in $\mathrm{Ca}$ as compared to the pigs fed the wheatbarley diet high in $\mathrm{Ca}$. Diets were formulated according to current recommendations for the nutrient requirements for pigs $^{(20,21)}$, and microbial phytase was added to increase the bioavailability of phytate-P. Dietary $\mathrm{Ca}$ and $\mathrm{P}$ analysis confirmed that the analysed dietary $\mathrm{Ca}$ and $\mathrm{P}$ concentrations were very similar as compared to the calculated dietary concentrations. Thus, the dietary $\mathrm{Ca}$ and $\mathrm{P}$ concentrations in the adequate diet should have met the actual dietary requirements of $\mathrm{Ca}$ and available $\mathrm{P}$ for $10-20 \mathrm{~kg}$ pigs. However, diet analysis also showed that the Ca:P ratio in the wheat-barley diet adequate in $\mathrm{Ca}$ was wider, at $1 \cdot 37: 1$, as compared to the wheat-barley diet high in $\mathrm{Ca}$, which had $\mathrm{Ca}$ and $\mathrm{P}$ concentrations in a ratio of $1 \cdot 24: 1$. This diverging $\mathrm{Ca}: \mathrm{P}$ ratio could have contributed to the present results for urinary $\mathrm{Ca}$

Table 8. Spearman's correlation coefficients for colonic gene expression and bacterial metabolites in the colonic digesta of pigs fed wheat-barley or maize diets adequate or high in calcium

\begin{tabular}{llrr}
\hline Bacterial metabolite* & Gene & \multicolumn{1}{c}{$r$} & \multicolumn{1}{c}{$P$} \\
\hline Acetate & INFG & 0.36 & 0.044 \\
Acetate & TNFA & 0.37 & 0.043 \\
Propionate & GLUT2 & 0.36 & 0.044 \\
Iso-butyrate & IL1B & -0.36 & 0.047 \\
Iso-butyrate & TLR4 & -0.43 & 0.017 \\
Valerate & TLR2 & -0.46 & 0.011 \\
Iso-valerate & TLR4 & -0.42 & 0.020 \\
Caproate & TLR2 & -0.60 & $<0.001$ \\
Lipopolysaccharide & IL1B & -0.53 & 0.002 \\
Lipopolysaccharide & IL6 & -0.60 & $<0.001$ \\
Lipopolysaccharide & IL10 & -0.58 & $<0.001$ \\
Lipopolysaccharide & TNFA & -0.62 & $<0.001$ \\
Lipopolysaccharide & TGFB1 & -0.48 & 0.006 \\
Lipopolysaccharide & TLR4 & -0.38 & 0.036 \\
\hline
\end{tabular}

INFG, interferon- $\gamma ;$ GLUT2, solute carrier family 2 (facilitated glucose transporter), member 2; TLR, toll-like receptor; TGFB1, transforming growth factor- $\beta 1$.

* Bacterial metabolite concentrations are published in MetzlerZebeli et al..$^{(17)}$. 
excretion and $\mathrm{Ca}$ and $\mathrm{P}$ retention when comparing the wheat-barley diet adequate in $\mathrm{Ca}$ to the wheat-barley diet high in $\mathrm{Ca}$. Aside from the ratio between $\mathrm{Ca}$ and available $\mathrm{P}$ being too wide, high concentrations of dietary protein also could have interfered with bone mineralisation ${ }^{(44)}$ by changing the acid-base balance ${ }^{(45)}$; this is particularly the case when diets contain rather low concentrations of $\mathrm{P}$, which is the current practice today ${ }^{(20,21)}$. Recommendations for the $\mathrm{P}$ requirements of pigs have been constantly reduced over the past two decades, mostly because of environmental and economic concerns ${ }^{(46,47)}$. Because microbial phytase was supplemented to the pigs' diet and wheat contains substantial intrinsic phytase activity, the role of dietary phytate may have been less pronounced, which would explain the lower availability of dietary $\mathrm{P}$ with the wheat-barley diets adequate in $\mathrm{Ca}$. Ion-binding capacity and rheological properties, such as viscosity, of dietary complex carbohydrates as well as microbial mineral demands on $\mathrm{P}$ and $\mathrm{Ca}$ for the fermentation of complex carbohydrates should be mentioned as further factors that may have influenced intestinal $\mathrm{Ca}$ and $\mathrm{P}$ availability ${ }^{(9,41-43,48)}$. For instance, negative effects of dietary supplementation of $5 \%$ microcrystalline cellulose on the apparent retention of $\mathrm{Ca}, \mathrm{Mg}, \mathrm{P}$ and trace elements were previously reported by our group, which indicated an increased daily requirement for minerals for growing pigs ${ }^{(43)}$.

The intestinal microbiota interacts with the host mucosa, thereby modulating mucosal gene expression ${ }^{(10)}$. In the present study, the up-regulated TLR2 expression in the jejunum of the pigs fed high Ca diets suggested a higher mucosal abundance of gram-positive bacteria in the jejunum as compared to the pigs fed the adequate $\mathrm{Ca}$ diets. Also, the maize diets up-regulated jejunal TLR2 expression as compared to the wheat-barley diets, probably because of the same reason. TLR belong to the family of pathogen-recognition receptors and are involved in the recognition of microbe-associated molecular patterns. TLR2 interacts with the cell wall components of gram-positive bacteria, including lipoteichoic acids, peptidoglycan and lipoproteins ${ }^{(49)}$. We did not quantify the bacterial microbiota at the jejunal mucosa. However, results from the stomach mucosa (Pars non-glandularis) and from gastric and ileal digesta indicated changes in the gram-positive bacterial composition as a result of dietary $\mathrm{Ca}$ and cereal composition. For instance, the pigs fed the high $v$. adequate Ca diets had considerably more lactobacilli-related OTU at the Pars nonglandularis of the stomach ${ }^{(18)}$. Accordingly, we observed an increase in the abundance of bifidobacteria in the gastric and ileal digesta of the pigs fed maize as compared to those fed wheat-barley diets ${ }^{(17)}$. Correlation coefficients for the colon further demonstrated that OTU which were related to the main phyla Bacteroidetes, Firmicutes and Proteobacteria, according to $97 \%$ sequence similarity as the cut-off for species level divergence, affected colonic gene expression. Because monocarboxylate transporters have different affinities for lactic acid and SCFA ${ }^{(50)}$, differences between the main fermentation metabolites of mucosa-associated OTU 1, 2, 27 and 89, with the closest reference strains being Lactobacillus johnsonii, Lactobacillus amylovorus, Lachnospiraceae bacterium and Eubacterium sp., respectively, likely explained the correlations with colonic monocarboxylate transporters expression. The closest reference strains to OTU 3 and 4, Lactobacillus mucosae and Lactobacillus delbrueckii ${ }^{(18)}$, have been shown to have immunomodulatory capacities ${ }^{(51)}$ which might have been reflected in the negative relation between OTU 3 and 4 and the colonic expression of pro-inflammatory cytokines and TGFB1, respectively. The modification of TGFB1 expression has been proposed as one possible mechanism related to immunological tolerance towards microbial components in the intestine ${ }^{(52)}$. Known probiotic immunomodulins include lactic acid, surface proteins of lactobacilli, peptidoglycan-derived neuropeptides, capric acid and histamine ${ }^{(51,53)}$. By contrast, OTU 624, with its closest reference strain being Campylobacter lanienae, might have been recognised by the immune system as a potential threat, and the colonic expression of TGFB1 and TNFA were therefore up-regulated. However, it should always be kept in mind that the taxonomic assignment of OTU to their closest reference strains is only an approximation of species classification. Present negative correlations between colonic cytokines genes and TLR4 gene expression and luminal LPS concentrations, in turn, may suggest that the present LPS was mostly of a nonharmful nature ${ }^{(54)}$. Sustained exposure to low concentrations of LPS is also known to induce the tolerant states that are typically associated with the decreased expression of pro-inflammatory cytokines $^{(55)}$, and this may also explain the negative correlations observed here. In addition, new data suggest that intestinal alkaline phosphatase play important protective roles in the detoxification of free LPS $^{(56)}$. Further research focusing on LPS immune reactivity, intestinal alkaline phosphatase and LPS tolerance is needed to establish the role of mucosal and systemic immune responses to luminal LPS in pigs.

In conclusion, high $\mathrm{Ca}$ diets increased intestinal $\mathrm{Ca}$ and $\mathrm{P}$ concentrations and modified the jejunal and colonic mucosal gene expression response. The observed effects of $\mathrm{Ca} \times$ cereal interaction on intestinal cytokine expression emphasise that the basal diet may intensify or alleviate certain Ca-related physiological effects. Overall, it appears that there is a stronger $\mathrm{Ca}$ effect in the small intestine than in the colon, which is in line with our previous study ${ }^{(9)}$. Shifts in bacterial composition caused by the diets might have been reflected in up-regulated jejunal TLR2 expression, whereas Spearman's correlations supported the close relationship between mucosal bacterial community and gene expression in the colon.

\section{Supplementary material}

To view supplementary material for this article, please visit http://dx.doi.org/10.1017/S0007114515000380

\section{Acknowledgements}

The authors thank the lab technicians of the Institute of Animal Nutrition and Functional Plant Compounds and the staff of the University Clinic for Swine for their assistance with sampling and laboratory analysis.

The present study was supported by Profile Lines of the Vetmeduni Vienna (B. U. M.-Z. Start-up project 'PL effects of calcium in weaned pigs'). 
B. U. M.-Z., S. S.-E., M. W., M. R. and Q. Z. designed the research; B. U. M.-Z. and E. M. conducted the research; R. E. and D. K. performed gene expression analysis; B. U. M.-Z. and Q. Z. performed statistical analysis; B. U. M.-Z. wrote the paper; and B. U. M.-Z. had primary responsibility for the final content. All authors read and approved the final manuscript

The authors declare no conflicts of interest.

\section{References}

1. Crenshaw TD (2001) Calcium, phosphorus, vitamin D, and vitamin K. In Swine Nutrition, 2nd ed., pp. 187-212 [AJ Lewis and LL Southern, editors]. Boca Raton, FL: CRC Press.

2. Soares MJ, Murhadi LL, Kurpad AV, et al. (2012) Mechanistic roles for calcium and vitamin $\mathrm{D}$ in the regulation of body weight. Obes Rev 13, 592-605.

3. Schepens MA, Schonewille AJ, Vink C, et al. (2009) Supplemental calcium attenuates the colitis-related increase in diarrhea, intestinal permeability, and extracellular matrix breakdown in HLA-B27 transgenic rats. $J$ Nutr 139, 1525-1533.

4. Schepens MA, Ten Bruggencate SJ, Schonewille AJ, et al. (2012) The protective effect of supplemental calcium on colonic permeability depends on a calcium phosphateinduced increase in luminal buffering capacity. Br J Nutr 107, 950-956.

5. Ten Bruggencate SJ, Snel J, Schoterman MH, et al. (2011) Efficacy of various dietary calcium salts to improve intestinal resistance to Salmonella infection in rats. Br J Nutr $\mathbf{1 0 5}$, 489-495.

6. Ballard ST, Hunter JH \& Taylor AE (1995) Regulation of tightjunction permeability during nutrient absorption across the intestinal epithelium. Annu Rev Nutr 15, 35-55.

7. Centeno V, de Barboza GD, Marchionatti A, et al. (2009) Molecular mechanisms triggered by low-calcium diets. Nutr Res Rev 22, 163-174.

8. van Ampting MT, Schonewille AJ, Vink C, et al. (2010) Damage to the intestinal epithelial barrier by antibiotic pretreatment of Salmonella-infected rats is lessened by dietary calcium or tannic acid. J Nutr 140, 2167-2172.

9. Metzler-Zebeli BU, Gänzle MG, Mosenthin R, et al. (2012) Oat $\beta$-glucan and dietary calcium and phosphorus differentially modify intestinal expression of proinflammatory cytokines and monocarboxylate transporter 1 and cecal morphology in weaned pigs. J Nutr 142, 668-674.

10. Bauer E, Metzler-Zebeli BU, Verstegen MW, et al. (2011) Intestinal gene expression in pigs: effects of reduced feed intake during weaning and potential impact of dietary components. Nutr Res Rev 24, 155-175.

11. Kim JC, Hansen CF, Mullan BP, et al. (2011) Nutrition and pathology of weaner pigs: nutritional strategies to support barrier function in the gastrointestinal tract. Anim Feed Sci Technol 173, 3-16.

12. Knudsen EKB (2011) Triennial growth symposium: effects of polymeric carbohydrates on growth and development in pigs. J Anim Sci 89, 1965-1980.

13. Shimizu M (2010) Interaction between food substances and the intestinal epithelium. Biosci Biotechnol Biochem $\mathbf{7 4}$, $232-241$

14. Leser TD \& Mølback L (2009) Better living through microbial action: the benefits of the mammalian gastrointestinal microbiota on the host. Environ Microbiol 11, 2194-2206.

15. Metzler-Zebeli BU, Zijlstra RT, Mosenthin R, et al. (2011) Dietary calcium phosphate content and oat $\beta$-glucan influence gastrointestinal microbiota, butyrate-producing bacteria and butyrate fermentation in weaned pigs. FEMS Microbiol Ecol 75, 402-413.

16. Dostal A, Fehlbaum S, Chassard C, et al. (2013) Low iron availability in continuous in vitro colonic fermentations induces strong dysbiosis of the child gut microbial consortium and a decrease in main metabolites. FEMS Microbiol Ecol $\mathbf{8 3}$, $161-175$.

17. Metzler-Zebeli BU, Mann E, Schmitz-Esser S, et al. (2013) Changing dietary calcium-phosphorus level and cereal source selectively alters abundance of bacteria and metabolites in the upper gastrointestinal tracts of weaned pigs. Appl Environ Microbiol 79, 7264-7272.

18. Mann E, Schmitz-Esser S, Zebeli Q, et al. (2014) Mucosaassociated bacterial microbiome of the gastrointestinal tract of weaned pigs and dynamics linked to dietary calciumphosphorus. PLOS ONE 9, e86950.

19. Metzler-Zebeli BU, Ertl R, Klein D, et al. (2014) Explorative study of metabolic adaptations to various dietary calcium intakes and cereal sources on serum metabolome and hepatic gene expression in juvenile pigs. Metabolomics (Epublication ahead of print version).

20. Gesellschaft für Ernährungsphysiologie (2006) Empfehlungen zur Energie- und Näbrstoffversorgung von Schweinen. Frankfurt am Main, Germany: DLG-Verlag.

21. Nutrient Research Council (2012) Nutrient Requirements of Swine, 11th ed. Washington, DC: National Academic Press.

22. Vandesompele J, De Preter K, Pattyn F, et al. (2003) Accurate normalization of real-time quantitative RT-PCR data by geometric averaging of multiple internal control genes. Genome Biol 3, RESEARCH0034

23. Livak KJ \& Schmittgen TD (2001) Analysis of relative gene expression data using real-time quantitative PCR and the $2^{-\Delta \Delta C T}$ method. Methods 25, 402-408.

24. VDLUFA (1976) Methodenbuch. Buch III: Die chemische Untersuchung von Futtermitteln, 3rd ed. Darmstadt, Germany: VDLUFA-Verlag.

25. Chen HH, Lin JH, Fung HP, et al. (2003) Serum acute phase proteins and swine health status. Can J Vet Sci 67, 283-290.

26. Schloss PD, Westcott SL, Ryabin T, et al. (2009) Introducing mothur: open-source, platform-independent, communitysupported software for describing and comparing microbial communities. Appl Environ Microbiol 75, 7537-7541.

27. Kuczinski J, Stombaugh J, Walters WA, et al. (2012) Using QIIME to analyze 16S rRNA gene sequences from microbial communities. Curr Protoc Microbiol 27, 1E.5.1-1.E.5.20.

28. Zhai H \& Adeola O (2013) True digestible phosphorus requirement of 10- to 20-kg pigs. J Anim Sci 91, 3716-3723.

29. Ukena SN, Singh A, Dringenberg U, et al. (2007) Probiotic Escherichia coli Nissle 1917 inhibits leaky gut by enhancing mucosal integrity. PLOS ONE 2, e1308.

30. Anderson JM \& Cerejido M (2001) Introduction: evolution of ideas on the tight junction. In Tight Junctions, pp. 1-18 [M Cereijido and JM Anderson, editors]. Boca Raton, FL: CRC Press.

31. Fujita H, Sugimoto K, Inatomi $S$, et al. (2008) Tight junction proteins claudin-2 and -12 are critical for vitamin D-dependent $\mathrm{Ca}^{2+}$ absorption between enterocytes. Mol Biol Cell 19, 1912-1921.

32. Hwang I, Yang H, Kang HS, et al. (2013) Alteration of tight junction gene expression by calcium- and vitamin D-deficient diet in the duodenum of calbindin-null mice. Int J Mol Sci 14, 22997-23010.

33. Schröder B \& Breves G (2006) Mechanisms and regulation of calcium absorption from the gastrointestinal tract in pigs and 
ruminants: comparative aspects with special emphasis on hypocalcemia in dairy cows. Anim Health Res Rev 7, 31-41.

34. Breves G, Schröder B \& Muscher A (2010) Luminal and endocrine factors for regulation of intestinal monosaccharide and $\mathrm{Ca}^{2+}$ transport. Livest Sci 134, 4-10.

35. Kellet GL (2011) Alternative perspective on intestinal calcium absorption: proposed complementary actions of $\mathrm{Ca}(\mathrm{v}) 1.3$ and TRPV6. Nutr Rev 69, 347-370.

36. Cuff MA, Lambert DW \& Shirazi-Beechey S (2002) Substrateinduced regulation of the human colonic monocarboxylate transporter, MCT1. J Physiol 539, 361-371.

37. Teramae H, Yoshikawa T, Inoue R, et al. (2010) The cellular expression of SMCT2 and its comparison with other transporters for monocarboxylates in the mouse digestive tract. Biomed Res 31, 239-249.

38. Che TM, Perez VG, Song M, et al. (2012) Effect of rice and other cereal grains on growth performance, pig removal, and antibiotic treatment of weaned pigs under commercial conditions. J Anim Sci 90, 4916-4924.

39. Wilamil J, Badiola I, Devillard E, et al. (2012) Wheat-barleyrye- or corn-fed growing pigs respond differently to dietary supplementation with a carbohydrase complex. J Anim Sci 90, 824-832.

40. Bendsen NT, Hother AL, Jensen SK, et al. (2008) Effect of dairy calcium on fecal fat excretion: a randomized crossover trial. Int J Obes 32, 1816-1824.

41. Grieshop CM, Reese DE \& Fahey GC Jr (2001) Nonstarch polysaccharides and oligosaccharides in swine nutrition. In Swine Nutrition, 2nd ed., pp. 187-212. Boca Raton, FL: CRC Press.

42. Metzler BU \& Mosenthin R (2008) A review of interactions between dietary fiber and the gastrointestinal microbiota and their consequences on intestinal phosphorus metabolism in growing pigs. Asian-Aust J Anim Sci 21, 603-615.

43. Metzler-Zebeli BU, Hooda S, Mosenthin R, et al. (2010) Bacterial fermentation affects net mineral flux in the large intestine of pigs fed diets with viscous and fermentable nonstarch polysaccharides. J Anim Sci 88, 3351-3362.

44. Varley PF, Flynn B, Callan JJ, et al. (2011) Effect of crude protein and phosphorus level on growth performance, bone mineralisation and phosphorus, calcium and nitrogen utilisation in grower-finisher pigs. Arch Anim Nutr 65, 134-147.

45. Arnett TR (2007) Acid-base regulation of bone metabolism. Int Congr Ser 1297, 255-267.

46. Selle PH \& Ravindran V (2008) Phytate-degrading enzymes in pig nutrition. Livest Sci 113, 99-122.

47. Cordell D, Drangert JO \& White S (2009) The story of phosphorus: global food security and food for thought. Global Environ Change 19, 292-305.

48. Metzler BU, Mosenthin R, Baumgärtel T, et al. (2008) The effect of dietary phosphorus and calcium level, phytase supplementation, and ileal infusion of pectin on the chemical composition and carbohydrase activity of fecal bacteria and the level of microbial metabolites in the gastrointestinal tract of pigs. J Anim Sci 86, 1544-1555.

49. van Bergenhenegouwen $\mathrm{J}$, Kraneveld $\mathrm{AD}$, Rutten $\mathrm{L}$, et al. (2014) Extracellular vesicles modulate host-microbe responses by altering TLR2 activity and phagocytosis. PLOS ONE 20, e89121.

50. Thwaites DT \& Anderson CM (2007) $\mathrm{H}^{+}$-coupled nutrient, micronutrient and drug transporters in the mammalian small intestine. Exp Physiol 92, 603-619.

51. Thomas CM \& Versalovics J (2010) Probiotics-host communication: modulation of signaling pathways in the intestine. Gut Microbes 1, 148-163.

52. Schiffrin EJ \& Blum S (2002) Interactions between the microbiota and the intestinal mucosa. Eur J Clin Nutr 56, Suppl. 3, S60-S64.

53. Thomas CM, Hong T, van Pijkeren JP, et al. (2012) Histamine derived from probiotic Lactobacillus reuteri suppresses TNF via modulation of PKA and ERK signaling. PLOS ONE 7, e31951.

54. Gabler NK \& Spurlock ME (2008) Integrating the immune system with the regulation of growth and efficiency. J Anim Sci 86, E64-E74.

55. West MA \& Heagy W (2002) Endotoxin tolerance: a review. Crit Care Med 30, S64-S73.

56. Lallès J-P (2014) Intestinal alkaline phosphatase: novel functions and protective effects. Nutr Rev 72, 82-94. 